\title{
An Alternative Treatment Method for Poisoning in Veterinary Medicine: Intravenous Lipid Emulsion
}

\author{
Büşra ASLAN AKYOL ${ }^{1 *}$, Cengiz GÖKBULUT ${ }^{\circledR}$ \\ ${ }^{1}$ Department of Pharmacology and Toxicology, CoHE 100/2000 Scholarship Holder, Faculty of Veterinary Medicine, Balikesir University,10145, \\ Balikesir, Turkey, ${ }^{2}$ Department of Medical Pharmacology, Faculty of Medicine, Balikesir University,10145, Balikesir, Turkey
}

\begin{abstract}
A B S T R A C T
Animal poison control centers receive numerous complaints about possible ingestion of substances that can cause deadly toxicities in the home. In recent years, over-the-counter medications such as ibuprofen, acetaminophen, and herbal supplements are the most common toxic substances ingested by pets. Removal of the toxin and supportive treatment is recommended in case of exposure to a toxin that does not have a known antidote. There have been many studies in both human and veterinary medicine that supporting the use of intravenous lipid emulsions in the treatment of intoxications. Intravenous lipid emulsion (ILE) is an oil-in-water emulsion that consists of egg yolk phospholipids, water, glycerin and various oils such as soybean, fish, coconut and olive oil. It is defined as a microemulsion with a long history of use as a parenteral nutrition formulation in both adult and pediatric patients. Also used as a drug carrier in addition to parenteral nutrition. In recent years, it has been used as an effective antidote for the treatment of intoxications caused by compounds with high oil solubility in both human and veterinary medicine. The first efficacy of the use of intravenous lipid emulsions in treatments was demonstrated in the systemic toxicity of local anesthetics and nowadays it comes to the fore in the poisoning of various drugs and compounds. However, it can also be used as an antidote in various intoxication cases caused by different chemicals that do not have any known antidote. Although clinically positive responses are received, more research is needed to more clearly understand the effect of intravenous lipid emulsion.

Keywords: Antidote, intravenous lipid emulsion, poisoning, toxicity
\end{abstract}

\section{Veteriner Hekimlikteki Zehirlenmelerde Alternatif Bir Tedavi Yöntemi: İntravenöz Lipit Emülsiyonu}

\section{ÖZET}

Hayvanlardaki toksikasyon vakalarında aktif görev alan kontrol yardım hatları, evlerde ölümcül toksisitelere neden olabilecek maddelerin muhtemel alımıyla ilgili çok sayıda şikâyet almaktadır. Son yıllarda ibuprofen, asetominofen ve bitkisel takviyeler gibi tezgâh üstü ilaçlar evcil hayvanlar tarafindan alınan en yaygın toksik maddelerdir. Bilinen bir antidotu olmayan toksinin alınmasında, mümkünse toksinin uzaklaştırılması ve destekleyici tedavinin yapılması önerilmektedir. Toksikasyonların önlenmesinde intravenöz lipit emülsiyonu kullanımını destekleyen hem beşerî hem de veteriner hekimliğinde birçok çalışma yapılmıştır. İntravenöz lipit emülsiyonu; yumurta fosfolipidleri, su, gliserin ve başta soya fasulyesi yağı olmak üzere balık, hindistan cevizi ile zeytin yağı gibi çeşitli bileşiklerden oluşan hem yetişkin hem de pediatrik hastalarda parenteral beslenme formülasyonu olarak uzun bir kullanım geçmişine sahip olan bir mikroemülsiyon olarak tanımlanır. Parenteral beslenmeye ek olarak ilaç taşıyıcısı olarak da kullanılmaktadır. Son yıllarda ise hem beşerî hem de veteriner hekimliğinde yağda çözünürlüğü yüksek olan bileşiklerin sebep olduğu toksikasyonlarda tedavi amacıyla etkin bir antidot olarak kullanılmaya başlanmıştır. Tedavilerdeki kullanımının ilk etkinliği lokal anesteziklerin sistemik toksisitesinde gösterilmiş olup, günümüzde çeşitli ilaç ve bileşiklerin sebep olduğu zehirlenmelerde ön plana çıkmaktadır. Bununla birlikte bilinen bir antidotu olmayan bileşiklerin neden olduğu zehirlenmelerde de antidot olarak kullanılabilmektedir. Her ne kadar klinik olarak olumlu yanıtlar alınıyor olsa da intravenöz lipit emülsiyon kullanımının etkisini daha net bir şekilde anlamak için daha fazla araştırmaya ihtiyaç vardır. Anahtar kelimeler: Antidot, intravenöz lipit emülsiyonu, zehirlenme, toksisite 


\section{Introduction}

Animal poison control centers (APCC) receive numerous calls about possible ingestion of substances that can cause deadly toxicities in the home. In 2020, over-thecounter medications such as ibuprofen, acetaminophen, and herbal supplements are the most common group of toxicants ingested by pets and $19.7 \%$ of incoming emergency calls. Also, human prescription drugs are in the second place with $17.2 \%$ of the cases. Other cases have been reported to be caused by foodstuffs such as onions and garlic, and substances such as rodenticide and insecticide/herbicide (ASPCA, 2021). Removal of the toxin and supportive treatment is recommended in case of exposure to a toxin that does not have a known antidote (Fernandez et al., 2011). In the last decade, there have been many studies in both human and veterinary fields supporting the administration of ILE (intravenous lipid emulsion) in the treatment of major intoxications (Fernandez et al., 2011; Rosenblatt et al., 2006; Weinberg et al., 1998).

Research on ILE, as a parenteral nutrition formulation, began in the 1970s (Krieglstein et al., 1974; Straathof et al., 1984). Its use in toxicology started with the treatment of experimental bupivacaine toxicity in the late 1990s (Weinberg et al., 1998). In cases of LAST (local anesthetic systemic toxicity) which standard resuscitation treatments were unsuccessful, positive responses could be obtained rapidly with the use of ILE (Weinberg et al., 2008; Weinberg, 2006). ILE, which is accepted as a treatment option for lipophilic drug toxicity in emergency departments and other critical care units, is also used for the treatment of LAST (Cave et al., 2010). However, it is also used as a treatment option for the toxicities of other lipophilic compounds, including herbicides and pesticides. The first use of ILE for therapeutic purposes in veterinary medicine was reported by Crandell and Weinberg (2009). A positive improvement was observed after the first application and a serious improvement was noted after the second application according to this study. However, it was reported that the neurological status returned to normal 6 hours after the application without recurrence (Crandell and Weinberg, 2009).

The aim of this review is to provide information to scientists and clinicians about the mechanism of action of ILE, dose recommendations in treatment protocols and potential side effects, by evaluating the existing experimental studies and case reports on the treatment of intoxications with ILE.

\section{ILE Formulations}

ILE is an oil-in-water emulsion which consists of egg yolk phospholipids, water, glycerin and various oils such as primarily soybean, fish, coconut and olive oil. $20 \%$ Intralipid emulsion, which is widely used in the treatment of lipophilic drug toxicity, consists of long-chain triglycerides originating from soybean oil (Charbonneau et al., 2009; Waitzberg et al., 2006). Emulsions containing soybean oil are the most commonly used lipid emulsions in parenteral nutrition and in the treatment of lipophilic drug toxicity, and they contain linoleic, oleic, palmitic, linolenic and stearic fatty acids. They also contain fish and evening primrose oil (Aljadani et al., 2020).

Commercially available ILE formulations (Intralipid, Liposyn III, Lipoplus, Lipoven, SMOFLipid, LipofundinMCT, Structolipid, Omegaven, Clinoleic) are listed in Table 1 (Fernandez et al., 2011). It consists of small liposome molecules, typically $80 \mathrm{~nm}$ in diameter. The liposome content is higher in a $10 \%$ emulsion compared to a $30 \%$ emulsion. This causes a higher level of emulsification of the oil rate. Due to the high liposome content, the catabolism of the liposomes is also high and causes the formation of lipoprotein-X. Intravascular accumulation of lipoprotein- $X$ may cause hypercholesterolemia. The oil concentration of the emulsion and the rate of administration, as well as the time of treatment, cause the deposition of liposomes and thus cholesterol. The daily given total amount of lipid is much lower in toxicological applications than recommended maximum amount in parenteral nutrition. Rapid administration of ILE is recommended in intoxicated patients to rapidly increase energy production, alter toxin kinetics, or rapidly create a "lipid sink" compartment within the intravascular space (Fernandez et al., 2011; Waitzberg et al., 2006).

\section{Mechanism of Action}

The mechanism of action of the ILE in toxicities has not been fully revealed and some hypotheses have been put forward (Cave and Harvey, 2014).

Table 1. Commercial preparations of ILE and fat contents (Fernandez et al., 2011)

\begin{tabular}{|l|l|l|}
\hline Preparation & Manufacturer & Fat Content \\
\hline Intralipit & Fresenius Kabi, Uppsala, Sweden & Soybean (\%100) \\
\hline Liposyn III & Hospira, Lake Forest, IL, USA & Soybean (\%100) \\
\hline Lipoven & Fresenius Kabi, Uppsala, Sweden & Soybean (\%100) \\
\hline Lipofundin-MCT & B. Braun, Melsungen, Germany & Coconut (\%50), Soybean (\%50) \\
\hline Structolipit & Fresenius Kabi, Uppsala, Sweden & Coconut (\%36), Soybean (\%64) \\
\hline Omegaven & Fresenius Kabi, Uppsala, Sweden & Fish (\%100) \\
\hline Lipoplus & B. Braun, Melsungen, Germany & Coconut (\%50), Soybean (\%40), Fish (\%10) \\
\hline Clinoleic & Baxter, Deerfield, IL, USA & Olive (\%80), Soybean (\%20) \\
\hline SMOFLipit & Fresenius Kabi, Uppsala, Sweden & Coconut (\%30), Soybean (\%30), Olive (\%25), Fish (\%15) \\
\hline
\end{tabular}


68

Table 2. Log P values of some lipophilic drugs that may cause toxicity (Fernandez et al., 2011)

\begin{tabular}{|l|l|l|l|}
\hline Drug & Log $\mathbf{P}$ & Drug & Log $\mathbf{P}$ \\
\hline Amlodipine & 1.90 & Lidocaine & 2.26 \\
\hline Baclofen & 1.30 & Loratadine & 5.20 \\
\hline Bupivacaine & 3.64 & Metoprolol & 1.88 \\
\hline Bupropion & 3.47 & Moxidectin & 4.10 \\
\hline Carbamazepine & 2.30 & Naproxen & 3.18 \\
\hline Carprofen & 4.13 & Ivermectin & 3.50 \\
\hline Chlorpheniramine & 3.17 & Nifedipine & 3.22 \\
\hline Chlorpromazine & 5.35 & Promethazine & 2.85 \\
\hline
\end{tabular}

The lipid sink phenomenon: The "lipid sink" phenomenon, primarily reported by Weinberg et al. (1998), is the most widely accepted mechanism of action for ILE. Administration of ILE formed an expanded intravascular lipid sink leads to the equilibrium, the toxic compound passes from the tissue to the liquid plasma phase and then to the lipid phase. Thus, leading to decrease the concentration of unbound toxin in plasma and distribution from organ and tissues to the bloodstream. Although the exact mechanism of action is not known, the binding property of the emulsion is probably the key criterion (Mazoit et al., 2009). Infusion of emulsified lipid droplets, into an aqueous medium such as blood, form a lipid compartment into which degraded lipophilic substances are collected. In particular, lipophilic substances such as local anesthetics are drawn into the "lipid sink", and the concentration gradient occurs between the tissue and blood, which allows the transition of lipophilic substances from high concentration to lipid compartment (Fernandez et al., 2011). Based on this hypothesis, ILE can be used in the treatment of intoxication caused by any lipophilic drug. Due to the log P value and thus lipophilicity, drugs or toxic substances are drawn into lipid compartments. Reaching high concentrations of drugs or toxic substances in the plasma results in less free toxic substance transfer to the tissues and therefore decrease the intoxication effects (Cave and Harvey, 2009; Picard and Meek, 2006; Straathof et al., 1984; Weinberg, 2003). The lipid sink phenomenon can be effectively used in the intoxications of chlorpromazine, bupropion, bupivacaine and some other lipophilic drugs ( $\log P>1.0)$ (Table 2) (Krieglstein et al., 1974; Litz et al., 2008; Sirianni et al., 2008; Weinberg et al., 1998, 2006).

Alternative Mechanisms: Under normal aerobic conditions, fatty acids are the preferred substrate for myocyte oxidative phosphorylation, and it is approximately $90 \%$ of cardiac ATP. Interruption of fatty acid transport reduces ATP production and leading to cardiac toxicity due to adversely affect myocyte survival (Collins-Nakai et al., 1994). Lipid emulsions contribute to improved ATP synthesis in cardiomyocytes by increasing the intracellular fatty acid content and inhibit the reduction of ATP synthesis resulting from local anesthetic blockade. Thus, myocardial ischemia can be prevented after ischemic reperfusion (Van de
Velde et al., 1996). Inhibition of mitochondrial fatty acid metabolism induced by toxic compounds is inhibited by ILE due to increasing the free fatty acid compartments. Local anesthetics that can be caused intoxication block the transport of fatty acids to mitochondria by inhibiting carnitine acylcarnitine translocase (Turner-Lawrence and Kerns, 2008). Through competitive inhibition or an unknown mechanism, ILE invalidates this inhibition and increases ATP production with the use of free fatty acids (Cave and Harvey, 2009).

The myocardial performance-enhancing effects are shaped by the increase of intracellular calcium concentration by ILE. Increased free fatty acids (especially stearate, linolenate, palmitate and oleate) stimulate the activation of voltage-dependent calcium channels in the myocardium and increase cytosolic calcium concentrations with cardiac function. However, it has been reported that increased intracellular calcium concentrations may have harmful effects, but this increase may contribute to the improvement of cardiac function in cases of secondary myocardial dysfunction due to calcium channel blocker toxicity (Turner-Lawrence and Kerns, 2008).

\section{Dosage Regimen Recommendations}

The recommended dose and rate of lipid emulsions for parenteral nutrition should also be considered for ILE administration in intoxication cases (Fernandez et al., 2011). In human medicine, the recommended dose for ILE is $2 \mathrm{~g} / \mathrm{kg} /$ day (Turner-Lawrence and Kerns, 2008). This dose can also be expressed by volume as $10 \mathrm{ml} /$ $\mathrm{kg} /$ day with $20 \%$ ILE. Recommended doses in veterinary medicine are similar to those in human medicine, but the doses may be exceeded due to parenteral nutrition requirements (Fernandez et al., 2011). The dose may need to be adapted for each lipophilic compound individually, depending on the degree of lipid solubility of the toxic compound (Hiller et al., 2010; Weinberg, 2003). Although optimal treatment protocols may vary between toxic compounds and species, different ILE protocols commonly used in veterinary medicine are listed in Table 3 (Felice and Schumann, 2008).

Most treatment protocols use $20 \%$ lipid solutions. It is usually administered as a slow bolus over several minutes and then as an infusion over 30-60 minutes via a venous catheter. The infusion should be administered at 
Table 3. Different ILE protocols commonly used in veterinary medicine

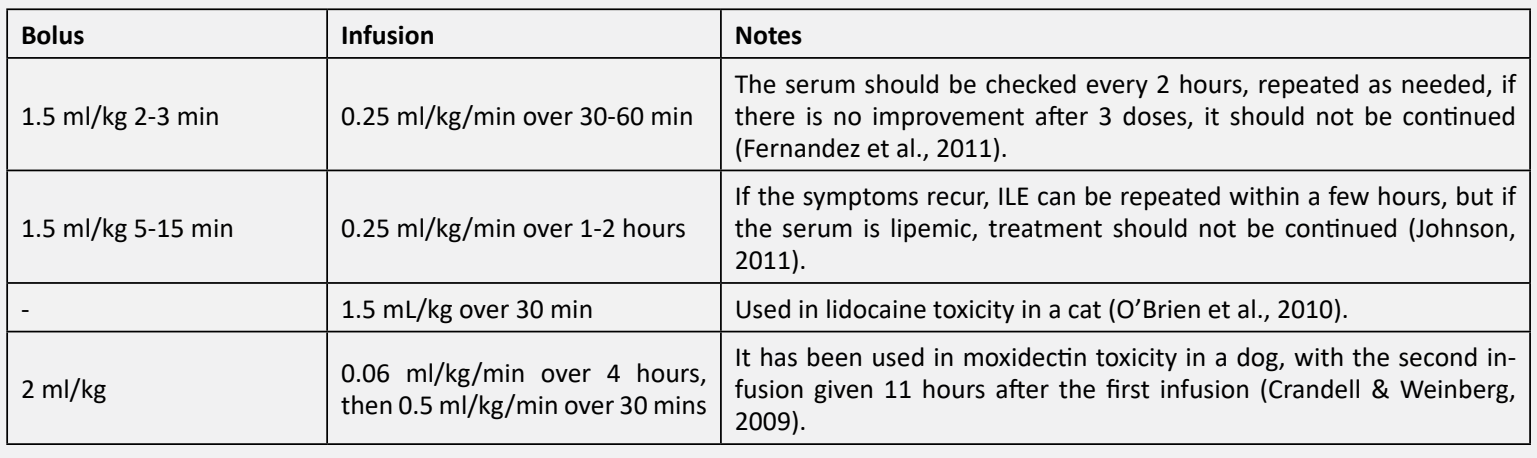

a dose of $0.11 \mathrm{~g} / \mathrm{kg} /$ hour and should not be administered at faster doses to avoid side effects. Serum should be monitored every two hours, and additional infusions should be considered if the patient is still symptomatic and there is no lipemia in the serum. If the serum turns orange or yellow, or if no improvement is noted after 3 doses, treatment with ILE should not be continued (Felice and Schumann, 2008). However, $20 \%$ formulations are generally preferred because they contain higher free phospholipids than $10 \%$ formulations. The potential for side effects may increase due to interactions of free phospholipids with lipoprotein lipase activity, which reduces the clearance of ILE (Weinberg, 2006).

\section{Side Effects}

Although side effects are rare, they may occur due to direct reaction to the emulsion or contamination of the emulsion. The contamination is particularly important for nutrient-rich products such as lipid emulsions. The use of inappropriate and non-sterile techniques may lead to microbial contamination. In addition, local or systemic infection and venous irritation may be observed with thrombophlebitis. An acute counter-pyrogenic reaction or a colloid reaction may be observed in direct reactions to the emulsion (Turner-Lawrence and Kerns, 2008). Allergic reactions may also occur to egg yolk phospholipid or soybean oil of formulation. Although clinical reactions are rare, they may include anaphylactic reaction-like symptoms that may occur within 20 minutes after administration. Fever, nausea, vomiting, dyspnea, tachypnea, cyanosis, arrhythmia, hypotension and cardiovascular collapse are among these symptoms (Driscoll, 2006; Felice and Schumann, 2008).

Subacute reactions to emulsion use may also occur and are often referred to as FOS (fat overload syndrome). It occurs as a result of excess volume or high administration rates that predominate endogenous lipid clearance mechanisms. FOS may also occur in patients with reduced plasma clearance of lipids. It may result in fat embolism, hyperlipidemia, hepatomegaly, icterus, splenomegaly, thrombocytopenia, increased clotting times and hemolysis (Turner-Lawrence and Kerns, 2008). Neurological complications such as multifocal deficiencies and focal seizures may also be observed in patients with FOS due to chronic lipid administration as a result of pathologies occurring in the brain tissue (Schulz et al., 1994).

The use of ILE may have adverse effects on the functions of the lungs and, however, the physiological effects may vary. An increase in pulmonary arterial pressure, decrease in partial arterial oxygen pressure to inspired oxygen level, increase in alveolar/arterial partial oxygen pressure and intrapulmonary shunt can be observed and these changes can be prevented by discontinuing the use of ILE. Changes in lung function are due to lipid metabolism products, decreased diffusion capacity due to lipid particle deposition in the reticuloendothelial system, and changes in pulmonary vascular tone, and secondary reduction of arterial oxygen. A rapid infusion of ILE should be carefully considered in patients with potential lung disease (Hwang et al., 1990; Venus et al., 1989).

Hypertriglyceridemia and lipemia have been accepted as inevitable consequences of ILE use and have been associated with the risk of cardiovascular disease and pancreatitis in humans $(\mathrm{Ng}, 2001)$. In dogs, it is thought to predispose to the development of pancreatitis and seizures (Xenoulis et al., 2008). However, an increased incidence of pancreatitis has been observed in dogs with primary hyperlipidemia (Westropp et al., 2005).

Specific formulations of ILE may have different physiological effects. Compared to emulsions containing 20\% Intralipid, 20\% Medialipid and omega-3 polyunsaturated fatty acids, Intralipid causes a slight increase in heart rate and a transient decrease in arterial $\mathrm{pH}$; others may lead to a decrease in myocardial contractile performance. For these reasons, care should also be taken in the selection of ILE formulations in animals with specific conditions (Van de Velde et al., 1998).

\section{Use of ILE in Veterinary Medicine}

It was first evaluated in vivo and in vitro with the chlorpromazine toxicity model in rabbits in 1974, and many experimental studies were conducted afterwards (Kaplan and Whelan, 2012; Krieglstein et al., 1974). The free chlorpromazine fraction was significantly reduced with the use of ILE in rabbits (Krieglstein et al., 1974). In addition, ILE co-administered with cyclosporine to rabbits reduced the total body clearance and volume of distribution of cyclosporine (Shah and Sawchuk, 1991). 
Table 4. ILE use with positive results in various intoxication cases

\begin{tabular}{|c|c|c|c|c|c|}
\hline Species & Compound & Symptoms & ILE & Dosage & Reference \\
\hline Cat & Baclofen & $\begin{array}{l}\text { Ataxia, } \\
\text { Mydriasis }\end{array}$ & \%20 Intralipid & $\begin{array}{l}2 \mathrm{ml} / \mathrm{kg} \text { bolus then } 15 \text { minutes } 0.05 \mathrm{ml} / \mathrm{kg} / \\
\mathrm{min} \text { over } 4 \text { hours }\end{array}$ & (Cavana, 2020) \\
\hline Cat & Carprofen & Hyperesthesia & $\% 20$ Intralipid & $\begin{array}{l}1.5 \mathrm{ml} / \mathrm{kg} \text { bolus then } 15 \text { minutes } 0.25 \mathrm{ml} / \\
\mathrm{kg} / \mathrm{min} \text { over } 1 \text { hour }\end{array}$ & $\begin{array}{l}\text { (Chumbler et al., } \\
\text { 2020) }\end{array}$ \\
\hline Dog & Permethrin & Tremor & $\% 20$ Intralipid & $\begin{array}{l}1.5 \mathrm{ml} / \mathrm{kg} \text { bolus then } 0.25 \mathrm{ml} / \mathrm{kg} / \mathrm{min} \text { over } \\
1 \text { hour }\end{array}$ & $\begin{array}{l}\text { (Kopke \& Yozova, } \\
\text { 2020) }\end{array}$ \\
\hline Dog & Chlorfenapyr & $\begin{array}{l}\text { Hyperemic } \\
\text { mucous memb- } \\
\text { ranes }\end{array}$ & $\% 20$ Intralipid & $1.5 \mathrm{ml} / \mathrm{kg}$ bolus then $15 \mathrm{ml} / \mathrm{kg}$ over 1 hour & (Davy et al., 2019) \\
\hline Dog & $\begin{array}{l}\text { Emodepside, } \\
\text { Praziquantel }\end{array}$ & $\begin{array}{l}\text { Tremor, } \\
\text { Ataxia }\end{array}$ & $\begin{array}{l}\text { \%20 Lipofun- } \\
\text { din }\end{array}$ & $2 \mathrm{ml} / \mathrm{kg}$ bolus then next hour $210 \mathrm{ml}$ & (Gaens et al., 2019) \\
\hline Dog & Lamotrigine & $\begin{array}{l}\text { Vomiting, } \\
\text { Lethargy }\end{array}$ & \%20 Intralipid & $\begin{array}{l}2 \mathrm{ml} / \mathrm{kg} \text { bolus then } 0.25 \mathrm{ml} / \mathrm{kg} / \mathrm{min} \text { over } \\
1 \text { hour }\end{array}$ & $\begin{array}{l}\text { (Bellis \& Gibeon, } \\
\text { 2018) }\end{array}$ \\
\hline Dog & Metaldehyde & $\begin{array}{l}\text { Tremor, } \\
\text { Loss of consci- } \\
\text { ousness }\end{array}$ & $\begin{array}{l}\text { \%20 Lipofun- } \\
\text { din }\end{array}$ & $\begin{array}{l}4 \mathrm{ml} / \mathrm{kg} \text { bolus then } 15 \mathrm{mins} \text { later } 0.25 \mathrm{ml} / \\
\mathrm{kg} / \mathrm{min} \text { over } 1 \text { hour }\end{array}$ & $\begin{array}{l}\text { (Lelescu et al., } \\
\text { 2017) }\end{array}$ \\
\hline Dog & Ivermectin & $\begin{array}{l}\text { Mydriasis, } \\
\text { Ataxia }\end{array}$ & $\% 20$ Intralipid & $\begin{array}{l}1.5 \mathrm{ml} / \mathrm{kg} \text { bolus then } 5 \mathrm{mins} \text { later } 0.25 \mathrm{ml} / \\
\mathrm{kg} / \mathrm{min} \text { over } 30 \mathrm{mins}\end{array}$ & (Pollio et al., 2018) \\
\hline Dog & Amplodipine & - & $\% 20$ Intralipid & $\begin{array}{l}1.5 \mathrm{ml} / \mathrm{kg} \text { bolus then } 5 \mathrm{mins} \text { later } 0.25 \mathrm{ml} / \\
\mathrm{kg} / \mathrm{min} \text { over } 1 \text { hour }\end{array}$ & $\begin{array}{l}\text { (Becker \& Young, } \\
\text { 2017) }\end{array}$ \\
\hline Dog & Loperamide & $\begin{array}{l}\text { Ataxia, } \\
\text { Salivation }\end{array}$ & $\% 20$ Intralipid & $\begin{array}{l}1.5 \mathrm{ml} / \mathrm{kg} \text { bolus then } 15 \mathrm{mins} \text { later } 0.25 \mathrm{ml} / \\
\mathrm{kg} / \mathrm{min} \text { over } 2 \text { hours }\end{array}$ & (Long et al., 2017) \\
\hline Dog & Bromethaline & Hyperaesthesia & $\% 20$ Intralipid & $\begin{array}{l}1.5 \mathrm{ml} / \mathrm{kg} \text { bolus then } 20 \mathrm{mins} \text { later } 0.38 \mathrm{ml} / \\
\mathrm{kg} / \mathrm{min} \text { over } 1 \text { hour }\end{array}$ & $\begin{array}{l}\text { (Heggem-Perry et } \\
\text { al., 2016) }\end{array}$ \\
\hline Dog & Moxidectin & $\begin{array}{l}\text { Tremor, } \\
\text { Pityalism }\end{array}$ & $\% 10$ Intralipid & $\begin{array}{l}3 \mathrm{ml} / \mathrm{kg} \text { bolus then } 10 \mathrm{mins} \text { later } 0.5 \mathrm{ml} / \mathrm{kg} / \\
\mathrm{min} \text { over } 30 \text { mins }\end{array}$ & (Sines, 2016) \\
\hline Dog & Vitamin $D_{3}$ & - & $\% 20$ Intralipid & $\begin{array}{l}1.5 \mathrm{ml} / \mathrm{kg} \text { bolus then } 15 \mathrm{mins} \text { later } 0.5 \mathrm{ml} / \\
\mathrm{kg} / \mathrm{min} \text { over } 30 \mathrm{mins}\end{array}$ & (Perry et al., 2016) \\
\hline Dog & Naproxen & - & $\% 20$ Intralipid & $\begin{array}{l}1.5 \mathrm{ml} / \mathrm{kg} \text { bolus then } 15 \mathrm{mins} \text { later } 0.31 \mathrm{ml} / \\
\mathrm{kg} / \mathrm{min} \text { over } 1 \text { hour }\end{array}$ & $\begin{array}{l}\text { (Herring et al., } \\
\text { 2015) }\end{array}$ \\
\hline Dog & $\begin{array}{l}\text { Synthetic Canna- } \\
\text { binoid }\end{array}$ & $\begin{array}{l}\text { Aggression, } \\
\text { Hyperaesthesia }\end{array}$ & $\% 20$ Intralipid & $1.5 \mathrm{ml} / \mathrm{kg}$ bolus then $0.5 \mathrm{ml} / \mathrm{kg} / \mathrm{hour}$ & $\begin{array}{l}\text { (Williams et al., } \\
\text { 2015) }\end{array}$ \\
\hline Dog & Ibuprofen & $\begin{array}{l}\text { Aggression, } \\
\text { Salivation }\end{array}$ & $\% 20$ Intralipid & $\begin{array}{l}1.5 \mathrm{ml} / \mathrm{kg} \text { bolus then } 15 \mathrm{mins} \text { later } 5 \mathrm{ml} / \mathrm{kg} / \\
\text { min over } 2 \text { hours }\end{array}$ & (Bolfer et al., 2014) \\
\hline Cat & Baclofen & Miosis & $\% 20$ Intralipid & $\begin{array}{l}1.5 \mathrm{ml} / \mathrm{kg} \text { bolus then } 90 \text { mins later } 7.5 \mathrm{ml} / \\
\mathrm{kg} / \mathrm{min} \text { over } 30 \text { mins }(x 2), 5 \text { mins later } \\
\text { same dosage infusion }\end{array}$ & $\begin{array}{l}\text { (Edwards et al., } \\
\text { 2014) }\end{array}$ \\
\hline Cat & Permethrin & $\begin{array}{l}\text { Tremor, Saliva- } \\
\text { tion }\end{array}$ & $\% 20$ Intralipid & $\begin{array}{l}1.5 \mathrm{ml} / \mathrm{kg} \text { bolus then } 0.25 \mathrm{ml} / \mathrm{kg} / \mathrm{min} \text { over } \\
1 \text { hour }\end{array}$ & (DeGroot, 2014) \\
\hline Dog & Diltiazem & - & $\% 20$ Intralipid & $\begin{array}{l}1.5 \mathrm{ml} / \mathrm{kg} \text { bolus }(\mathrm{x} 2) \text { then } 0.25 \mathrm{ml} / \mathrm{kg} / \text { hour } \\
\text { over } 1 \text { hour and } 0.4-0.5 \mathrm{ml} / \mathrm{kg} / \text { hour over } \\
16 \text { hours }\end{array}$ & $\begin{array}{l}\text { (Maton et al., } \\
\text { 2013) }\end{array}$ \\
\hline Horse & $\begin{array}{l}\text { Ivermectin } \\
\text { Praziquantel }\end{array}$ & $\begin{array}{l}\text { Tremor, } \\
\text { Nystagmus }\end{array}$ & $\% 20$ Intralipid & $\begin{array}{l}1.5 \mathrm{ml} / \mathrm{kg} \text { bolus then } 0.25 \mathrm{ml} / \mathrm{kg} / \mathrm{min} \text { over } \\
30 \mathrm{mins}\end{array}$ & $\begin{array}{l}\text { (Bruenisholz et al., } \\
\text { 2012) }\end{array}$ \\
\hline Cat & Permethrin & Tremor & $\% 20$ Ivelip & $\begin{array}{l}1.5 \mathrm{ml} / \mathrm{kg} \text { bolus then } 30 \mathrm{mins} \text { later } 0.25 \mathrm{ml} / \\
\mathrm{kg} / \mathrm{min} \text { over } 45 \mathrm{mins}\end{array}$ & $\begin{array}{l}\text { (Haworth \& Smart, } \\
\text { 2012) }\end{array}$ \\
\hline Dog & Ivermectin & $\begin{array}{l}\text { Ataxia, } \\
\text { Depression, } \\
\text { Tremor }\end{array}$ & \%20 Liposyn II & $\begin{array}{l}1.5 \mathrm{ml} / \mathrm{kg} \text { bolus then } 0.25 \mathrm{ml} / \mathrm{kg} / \text { hour over } \\
14 \text { hours, next day } 7.5 \mathrm{ml} / \mathrm{kg} \text { bolus ( } 2 \text { ) }\end{array}$ & $\begin{array}{l}\text { (Wright et al., } \\
\text { 2011) }\end{array}$ \\
\hline Dog & Ivermectin & $\begin{array}{l}\text { Tremor, } \\
\text { Miosis }\end{array}$ & \%20 Liposyn II & $\begin{array}{l}1.5 \mathrm{ml} / \mathrm{kg} \text { bolus then } 0.5 \mathrm{ml} / \mathrm{kg} / \mathrm{min} \text { over } \\
30 \mathrm{mins}\end{array}$ & $\begin{array}{l}\text { (Wright et al., } \\
\text { 2011) }\end{array}$ \\
\hline Cat & Lidocaine & Lethargy & \%20 Intralipid & $3 \mathrm{ml} / \mathrm{kg}$ bolus & $\begin{array}{l}\text { (O'Brien et al., } \\
2010)\end{array}$ \\
\hline Dog & Moxidectin & $\begin{array}{l}\text { Ataxia, } \\
\text { Tremor }\end{array}$ & $\% 20$ Intralipid & $6.5 \mathrm{ml}$ bolus then $12 \mathrm{ml} /$ hour over 4 hours & $\begin{array}{l}\text { (Crandell \& Wein- } \\
\text { berg, 2009) }\end{array}$ \\
\hline
\end{tabular}


ILE has been used effectively in LAST cases in animals (Hoegberg et al., 2016). Use of ILE, especially in bupivacaine-induced asystole; the $\mathrm{LD}_{50}$ value of bupivacaine can be increased by approximately $50 \%$ (Weinberg et al., 1998), a faster return to the spontaneous circulation can be achieved, and with positive progress in cardiac functions, bupivacaine in the heart tissue can be rapidly reduced at the same time (Weinberg et al., 2006). ILE can also be used in the treatment of bupivacaineinduced cardiotoxicity. It has been reported that all patients who underwent ILE survived, even in dogs who developed cardiac arrest, and that blood pressure and pulse returned to normal levels 30 minutes after the use of ILE (Weinberg, 2003).

In addition to local anesthetics, ILE can also be used in the intoxication of lipophilic compounds (Levine et al., 2016). The efficacy of the use of ILE in the treatment of clomipramine-induced hypotension in rabbits has been reported (Harvey and Cave, 2007). However, similar results have been reported in the evaluation of respiratory depression caused by thiopentone, cardiotoxicity of verapamil, and hypotension induced by propranolol (Cave et al., 2005; Harvey and Cave, 2008; Tebbutt, 2006).

A case report on the successful use of ILE in the treatment of moxidectin toxicity was first reported in 2009 (Crandell and Weinberg, 2009). Subsequently, many case reports of the use of ILE in the treatment of various types and intoxications have been published (Bischoff et al., 2014; Bruenisholz et al., 2012; Robben and Dijkman, 2017; Saqib et al., 2015; West and Rusbridge, 2021). According to these studies, the use of ILE can be success in most of the intoxications. Although positive responses have been reported, the use of ILE may fail in some disulfoton, ivermectin and bromethalin toxicity. It is thought that ABCB1 mutants (defective P-glycoprotein) may be responsible for this failure (Becker and Young, 2017; Wright et al., 2011).

The use of ILE in the treatment of various toxic substances (such as amlodipine, baclofen, diltiazem, lamotrigine, local anesthetics, loperamide, macrocyclic lactones, permethrin, synthetic cannabinoids, tremorgenic mycotoxins, Pieris Japonica) is summarized in Table 4. Experimental studies in animal and human clinical cases have shown that $\beta$-blockers, bupropion, bupivacaine, carbamazepine, clomipramine, doxepin, flecainide, hydroxychloroquine, and verapamil toxicity respond to the use of ILE (Fernandez et al., 2011). However, determining the responses of intoxications to the application is not as easy as determining the lipophilicity of the toxic substance. Because, some weak lipophilic toxic substances (baclofen, Log $P$ 1.30) have been reported to respond well to the use of ILE, suggesting that other physicochemical factors such as electrostatic interactions may also be effective (AbdelHafez and Abdel-Wahab, 2008; Fettiplace and Weinberg, 2018). Failure of the use of antidotal ILE; It may be due to incompatibility between the toxic substance and ILE, insufficient dosing or infusion rates, other factors yet to be discovered, and its determination is difficult due to the lack of knowledge about the mechanism of action of ILE (Tampakis et al., 2020).

It has been reported that $20 \%$ of formulations are more effective than $10 \%$ ILE in most intoxication cases, however, $30 \%$ of formulations can provide a faster recovery in severe cardiotoxicity cases (Fettiplace et al., 2014). Infusion dose and rate differ in veterinary patients (Table 3,4). When adequate clinical improvement is observed following administration, patients should be monitored for at least 12 hours for return of clinical symptoms or delayed allergic responses (Robben and Dijkman, 2017).

\section{Conclusion}

In recent years, ILE has been used as an effective antidote for the treatment of intoxication cases of compounds with high oil solubility in both human and veterinary medicine. Administered ILE provides an extended intravascular lipid phase by sequestering lipidsoluble toxic compounds from target tissues, lowering free drug/toxin levels, thereby reducing toxic effects. As a result, it is thought that elimination is accelerated by drawing the drug from the target tissues into the systemic circulation through the lipid phase formed in the systemic circulation. Based on this hypothesis, ILE is considered a treatment option for any lipophilic compound toxicity. However, advantages such as clinical improvement, relatively easy administration, and low cost have led to increased off-label use of ILE. Although it is useful in the treatment of toxicities, the possible risks and side effects against its beneficial effects have not been fully defined. However, there is no safe dosage protocol due to off-label use. Therefore, a benefit-risk analysis should be performed for each patient before using ILE. In addition, the effect of ILE administration on the pharmacokinetic/toxicokinetic behavior of the toxic compounds has not been clearly demonstrated. Therefore, new studies are needed to determine the efficacy and safety of ILE, which is used as an antidote in the treatment of intoxications, as well as to establish an effective and safe dosing regimen in veterinary medicine.

\section{Conflict of Interest}

The authors declare that they have no conflicts of interest.

\section{References}

Abdel-Hafez, A. A., \& Abdel-Wahab, B. A. (2008). 5-(4-Chlorophenyl)5,6-dihydro-1,3-oxazepin-7(4H)-one derivatives as lipophilic cyclic analogues of baclofen: Design, synthesis, and neuropharmacological evaluation. Bioorganic \& Medicinal Chemistry, 16(17), 7983-7991. https://doi.org/10.1016/j.bmc.2008.07.064

Aljadani, N. A., Elnaggar, M. H. R., \& Assaggaff, A. I. (2020). The role of fish oil and evening primrose oil against the toxicity of fenitrothion pesticide in male rats. International Journal of Pharmaceutical Research \& Allied Sciences, 9(2).

ASPCA. (2021). Top 10 pet poisons of the year. American Society for the Prevention of Cruelty to Animals. https://www.aspca.org/news/ announcing-top-10-pet-toxins (accessed 3 September 2021).

Becker, M., \& Young, B. (2017). Treatment of severe lipophilic intoxications with intravenous lipid emulsion: a case series (20112014). Veterinary Medicine: Research and Reports, 8, 77-85. https://doi.org/10.2147/VMRR.S129576 
Bellis, T. J., \& Gibeon, L. (2018). The use of intralipid emulsion therapy to treat severe cardiotoxicity secondary to lamotrigine ingestion in a dog. Clinical Case Reports, 6(10), 1982-1988. https://doi. org/10.1002/ccr3.1733

Bischoff, K., Smith, M. C., \& Stump, S. (2014). Treatment of Pieris Ingestion in Goats with Intravenous Lipid Emulsion. Journal of Medical Toxicology, 10(4), 411-414. https://doi.org/10.1007/ s13181-014-0426-z

Bolfer, L., McMichael, M., Ngwenyama, T. R., \& O’Brien, M. A. (2014) Treatment of Ibuprofen Toxicosis in a Dog with IV Lipid Emulsion. Journal of the American Animal Hospital Association, 50(2), 136140. https://doi.org/10.5326/JAAHA-MS-5979

Bruenisholz, H., Kupper, J., Muentener, C. R., Dally, A., Kraemer, T., Naegeli, H., \& Schwarzwald, C. C. (2012). Treatment of Ivermectin Overdose in a Miniature Shetland Pony Using Intravenous Administration of a Lipid Emulsion. Journal of Veterinary Internal Medicine, 26(2), 407-411. https://doi.org/10.1111/j.19391676.2011.00865.x

Cavana, P. (2020). Use of Intravenously Lipid Emulsion for Treatment of Baclofen Toxicosis in a Cat. Pakistan Veterinary Journal, 40(1), 133-135. https://doi.org/10.29261/pakvetj/2019.123

Cave, G, Harrop Griffiths, W., Harvey, M., Meek, T., Picard, J., Short, T., \& Weinberg, G. (2010). Safety Guideline, Management of Severe Local Anaesthetic Toxicity. https://anaesthetists.org/Portals/0/ PDFs/Guidelines PDFs/Guideline_management_severe_local anaesthetic toxicity v2 2010 final.pdf?ver=2018-07-11-163755240\&ver=2018-07-11-163755-240 (accessed 3 September 2021).

Cave, G. \& Harvey, M. (2009). Intravenous Lipid Emulsion as Antidote Beyond Local Anesthetic Toxicity: A Systematic Review. Academic Emergency Medicine, 16(9), 815-824. https://doi.org/10.1111/ j.1553-2712.2009.00499.x

Cave, G. \& Harvey, M. G. (2014). Should we consider the infusion of lipid emulsion in the resuscitation of poisoned patients? Critical Care, 18(5), 457. https://doi.org/10.1186/s13054-014-0457-5

Cave, G., Harvey, M. G., \& Castle, C. D. (2005). Intralipid ameliorates thiopentone induced respiratory depression in rats: Investigative pilot study. Emergency Medicine Australasia, 17(2), 180-181. https://doi.org/10.1111/j.1742-6723.2005.00714.x

Charbonneau, H., Marcou, T. A. P., Mazoit, J.-X., Zetlaoui, P. J., \& Benhamou, D. (2009). Early Use of Lipid Emulsion To Treat Incipient Mepivacaine Intoxication. Regional Anesthesia and Pain Medicine, 34(3), 277-278. https://doi.org/10.1097/AAP.0b013e31819340be

Chumbler, N. S., Schildt, J. C., Mawby, D. I., \& Papich, M. G. (2020) Use of intravenous lipid therapy in a cat with carprofen overdose. Clinical Case Reports, 8(4), 653-657. https://doi.org/10.1002/ ccr3.2772

Collins-Nakai, R. L., Noseworthy, D., \& Lopaschuk, G. D. (1994) Epinephrine increases ATP production in hearts by preferentially increasing glucose metabolism. American Journal of PhysiologyHeart and Circulatory Physiology, 267(5), H1862-H1871. https:// doi.org/10.1152/ajpheart.1994.267.5.H1862

Crandell, D. E., \& Weinberg, G. L. (2009). Moxidectin toxicosis in a puppy successfully treated with intravenous lipids. Journal of Veterinary Emergency and Critical Care, 19(2), 181-186. https:// doi.org/10.1111/j.1476-4431.2009.00402.x

Davy, R. B., Campos, S., \& Lynch, A. M. (2019). Acute chlorfenapyr toxicity in 3 dogs from a single household. Journal of Veterinary Emergency and Critical Care, 29(6), 686-689. https://doi. org/10.1111/vec.12894

DeGroot, W. D. (2014). Intravenous lipid emulsion for treating permethrin toxicosis in a cat. The Canadian Veterinary Journal, 55(1), 1253.

Driscoll, D. F. (2006). Lipid Injectable Emulsions: Pharmacopeial and Safety Issues. Pharmaceutical Research, 23(9), 1959-1969. https:// doi.org/10.1007/s11095-006-9092-4

Edwards, P., Shihab, N., \& Scott, H. W. (2014). Treatment of a case of feline baclofen toxicosis with intravenous lipid therapy. Veterinary Record Case Reports, 2(1). https://doi.org/10.1136/ vetreccr-2014-000059

Felice, K. L., \& Schumann, H. M. (2008). Intravenous lipid emulsion for local anesthetic toxicity: A review of the literature. Journal of Medical Toxicology, 4(3), 184-191. https://doi.org/10.1007/
BF03161199

Fernandez, A. L., Lee, J. A., Rahilly, L., Hovda, L., Brutlag, A. G., \& Engebretsen, K. (2011). The use of intravenous lipid emulsion as an antidote in veterinary toxicology. Journal of Veterinary Emergency and Critical Care, 21(4), 309-320. https://doi.org/10.1111/j.14764431.2011.00657.x

Fettiplace, M. R., Akpa, B. S., Ripper, R., Zider, B., Lang, J., Rubinstein, I., \& Weinberg, G. (2014). Resuscitation with lipid emulsion: dosedependent recovery from cardiac pharmacotoxicity requires a cardiotonic effect. Anesthesiology, 120(4), 915-925. https://doi. org/10.1097/ALN.0000000000000142

Fettiplace, M. R., \& Weinberg, G. (2018). The Mechanisms Underlying Lipid Resuscitation Therapy. Regional Anesthesia and Pain Medicine, 43(2), 138-149. https://doi.org/10.1097/AAP.0000000000000719

Gaens, D., Leithäuser, C., Hamann, M., \& Geyer, J. (2019). Adverse Drug Reactions After Administration of Emodepside/Praziquantel (Profender ${ }^{\circledR}$ ) in an MDR1-Mutant Australian Shepherd Dog: Case Report. Frontiers in Veterinary Science, 6, 296. https://doi. org/10.3389/fvets.2019.00296

Harvey, M., \& Cave, G. (2007). Intralipid Outperforms Sodium Bicarbonate in a Rabbit Model of Clomipramine Toxicity. Annals of Emergency Medicine, 49(2), 178-185.e4. https://doi.org/10.1016/j. annemergmed.2006.07.016

Harvey, M. G., \& Cave, G. R. (2008). Intralipid infusion ameliorates propranolol-induced hypotension in rabbits. Journal of Medical Toxicology, 4(2), 71-76. https://doi.org/10.1007/BF03160958

Haworth, M. D., \& Smart, L. (2012). Use of intravenous lipid therapy in three cases of feline permethrin toxicosis. Journal of Veterinary Emergency and Critical Care, 22(6), 697-702. https://doi. org/10.1111/j.1476-4431.2012.00804.x

Heggem-Perry, B., McMichael, M., O’Brien, M., \& Moran, C. (2016). Intravenous Lipid Emulsion Therapy for Bromethalin Toxicity in a Dog. Journal of the American Animal Hospital Association, 52(4), 265-268. https://doi.org/10.5326/JAAHA-MS-6396

Herring, J. M., McMichael, M. A., Corsi, R., \& Wurlod, V. (2015). Intravenous lipid emulsion therapy in three cases of canine naproxen overdose. Journal of Veterinary Emergency and Critical Care, 25(5), 672-678. https://doi.org/10.1111/vec.12307

Hiller, D. B., Di Gregorio, G., Kelly, K., Ripper, R., Edelman, L., Boumendjel, R., Drasner, K., \& Weinberg, G. L. (2010). Safety of High Volume Lipid Emulsion Infusion. Regional Anesthesia and Pain Medicine, 35(2), 140-144. https://doi.org/10.1097/AAP.0b013e3181c6f5aa

Hoegberg, L. C. G., Bania, T. C., Lavergne, V., Bailey, B., Turgeon, A. F., Thomas, S. H. L., Morris, M., Miller-Nesbitt, A., Mégarbane, B., Magder, S., \& Gosselin, S. (2016). Systematic review of the effect of intravenous lipid emulsion therapy for local anesthetic toxicity. Clinical Toxicology, 54(3), 167-193. https://doi.org/10.3109/15563 650.2015 .1121270

Hwang, T.-L., Huang, S.-L., \& Chen, M.-F. (1990). Effects of Intravenous Fat Emulsion on Respiratory Failure. Chest, 97(4), 934-938. https:// doi.org/10.1378/chest.97.4.934

Johnson, T. (2011). Intravenous lipid emulsion (IVLE) therapy for selected toxicoses. Proeedings of the Interntional Veterinary Emergency and Critical Care Society, San Antonio, TX, USA.

Kaplan, A., \& Whelan, M. (2012). The Use of IV Lipid Emulsion for Lipophilic Drug Toxicities. Journal of the American Animal Hospital Association, 48(4), 221-227. https://doi.org/10.5326/JAAHAMS-5761

Kopke, M. A., \& Yozova, I. D. (2020). Management of presumptive canine permethrin toxicosis using intravenous lipid emulsion as an adjunctive therapy. Veterinary Record Case Reports, 8(2), e001041. https://doi.org/10.1136/vetreccr-2019-001041

Krieglstein, J., Meffert, A., \& Niemeyer, D. H. (1974). Influence of emulsified fat on chlorpromazine availability in rabbit blood. Experientia, 30(8), 924-926. https://doi.org/10.1007/BF01938365

Lelescu, C. A., Mureșan, C., Muste, A., Taulescu, M. A., Neagu, A. M., \& Nagy, A. L. (2017). Successful treatment of metaldehyde toxicosis with intravenous lipid emulsion in a dog. Acta Veterinaria Brno, 86(4), 379-383. https://doi.org/10.2754/avb201786040379

Levine, M., Hoffman, R. S., Lavergne, V., Stork, C. M., Graudins, A., Chuang, R., Stellpflug, S. J., Morris, M., Miller-Nesbitt, A., \& 
Gosselin, S. (2016). Systematic review of the effect of intravenous lipid emulsion therapy for non-local anesthetics toxicity. Clinical Toxicology, 54(3), 194-221. https://doi.org/10.3109/15563650.20 15.1126286

Litz, R. J., Roessel, T., Heller, A. R., \& Stehr, S. N. (2008). Reversal of Central Nervous System and Cardiac Toxicity After Local Anesthetic Intoxication by Lipid Emulsion Injection. Anesthesia \& Analgesia, 106(5), 1575-1577. https://doi.org/10.1213/ ane.0b013e3181683dd7

Long, W. M., Sinnott, V. B., Bracker, K., \& Thomas, D. (2017). Use of $20 \%$ intravenous lipid emulsion for the treatment of loperamide toxicosis in a Collie homozygous for the ABCB1-1 $\triangle$ mutation. Journal of Veterinary Emergency and Critical Care, 27(3), 357-361. https://doi.org/10.1111/vec.12562

Maton, B. L., Simmonds, E. E., Lee, J. A., \& Alwood, A. J. (2013). The use of high-dose insulin therapy and intravenous lipid emulsion to treat severe, refractory diltiazem toxicosis in a dog. Journal of Veterinary Emergency and Critical Care, 23(3), 321-327. https:// doi.org/10.1111/vec.12053

Mazoit, J.-X., Le Guen, R., Beloeil, H., \& Benhamou, D. (2009). Binding of Long-lasting Local Anesthetics to Lipid Emulsions. Anesthesiology, 110(2), 380-386. https://doi.org/10.1097/ALN.0b013e318194b252

$\mathrm{Ng}$, D. (2001). Heparin in hypertriglyceridemia: Friend or foe? Journal of Laboratory and Clinical Medicine, 138(6), 356-358. https://doi. org/10.1067/mlc.2001.119433

O’Brien, T. Q., Clark-Price, S. C., Evans, E. E., Di Fazio, R., \& McMichael, M. A. (2010). Infusion of a lipid emulsion to treat lidocaine intoxication in a cat. Journal of the American Veterinary Medical Association, 237(12), 1455-1458. https://doi.org/10.2460/javma.237.12.1455

Perry, B. H., McMichael, M., Rick, M., \& Jewell, E. (2016). Reduction of serum 25-hydroxyvitamin $D$ concentrations with intravenous lipid emulsion in a dog. The Canadian Veterinary Journal, 57(12), 1284.

Picard, J., \& Meek, T. (2006). Lipid emulsion to treat overdose of local anaesthetic: the gift of the glob. Anaesthesia, 61(2), 107-109. https://doi.org/10.1111/j.1365-2044.2005.04494.x

Pollio, D., Michau, T. M., Weaver, E., \& Kuebelbeck, K. L. (2018). Electroretinographic changes after intravenous lipid emulsion therapy in a dog and a foal with ivermectin toxicosis. Veterinary Ophthalmology, 21(1), 82-87. https://doi.org/10.1111/vop.12410

Robben, J. H., \& Dijkman, M. A. (2017). Lipid Therapy for Intoxications. Veterinary Clinics of North America: Small Animal Practice, 47(2), 435-450. https://doi.org/10.1016/j.cvsm.2016.10.018

Rosenblatt, M. A., Abel, M., Fischer, G. W., Itzkovich, C. J., \& Eisenkraft, J. B. (2006). Successful Use of a $20 \%$ Lipid Emulsion to Resuscitate a Patient after a Presumed Bupivacaine-related Cardiac Arrest. Anesthesiology, 105(1), 217-218. https://doi. org/10.1097/00000542-200607000-00033

Saqib, M., Abbas, G., \& Mughal, M. N. (2015). Successful management of ivermectin-induced blindness in an African lion (Panthera leo) by intravenous administration of a lipid emulsion. BMC Veterinary Research, 11(1), 287. https://doi.org/10.1186/s12917-015-0603-6

Schulz, P. E., Weiner, S. P., Haber, L. M., Armstrong, D. D., \& Fishman, M. A. (1994). Neurological complications from fat emulsion therapy. Annals of Neurology, 35(5), 628-630. https://doi.org/10.1002/ ana.410350521

Shah, A. K., \& Sawchuk, R. J. (1991). Effect of co-administration of intralipidTM on the pharmacokinetics of cyclosporine in the rabbit. Biopharmaceutics \& Drug Disposition, 12(6), 457-466. https://doi. org/10.1002/bdd.2510120607

Sines, D. (2016). Moxidectin intoxication in a dog - a patient care report. The Veterinary Nurse, 7(3), 182-186. https://doi. org/10.12968/vetn.2016.7.3.182

Sirianni, A. J., Osterhoudt, K. C., Calello, D. P., Muller, A. A., Waterhouse, M. R., Goodkin, M. B., Weinberg, G. L., \& Henretig, F. M. (2008). Use of Lipid Emulsion in the Resuscitation of a Patient With Prolonged Cardiovascular Collapse After Overdose of Bupropion and Lamotrigine. Annals of Emergency Medicine, 51(4), 412-415. e1. https://doi.org/10.1016/j.annemergmed.2007.06.004

Straathof, D. J., Driessen, O., Meijer, J. W., Van Rees, H., Vermeij, P., \& Vermeij, T. A. (1984). Influence of Intralipid infusion on the elimination of phenytoin. Archives Internationales de Pharmacodynamie et de Thérapie, 267(2), 180-186.
Tampakis, K., Vogiatzakis, N., Kontogiannis, C., Spartalis, M., Ntalianis, A., Spartalis, E., Siafaka, I., lacovidou, N., Chalkias, A., \& Xanthos, T. (2020). Intravenous lipid emulsion as an antidote in clinical toxicology: a systematic review. European Review for Medical and Pharmacological Sciences, 24(12), 7138-7148. https://doi. org/10.26355/eurrev_202006_21708

Tebbutt, S. (2006). Intralipid Prolongs Survival in a Rat Model of Verapamil Toxicity. Academic Emergency Medicine, 13(2), 134-139. https://doi.org/10.1197/j.aem.2005.08.016

Turner-Lawrence, D. E., \& Kerns, W. (2008). Intravenous fat emulsion: A potential novel antidote. Journal of Medical Toxicology, 4(2), 109114. https://doi.org/10.1007/BF03160965

Van de Velde, M., Wouters, P. F., Rolf, N., Van Aken, H., \& Vandermeersch, E. (1998). Comparative hemodynamic effects of three different parenterally administered lipid emulsions in conscious dogs. Critical Care Medicine, 26(1), 132-137. https://doi.org/10.1097/00003246199801000-00028

Van de Velde, M., Wouters, P., Rolf, N., Van Aken, H., Flameng, W., \& Vandermeersch, E. (1996). Long-chain triglycerides improve recovery from myocardial stunning in conscious dogs. Cardiovascular Research, 32(6), 1008-1015. https://doi. org/10.1016/S0008-6363(96)00165-4

Venus, B., Smith, R. A., Patel, C., \& Sandoval, E. (1989). Hemodynamic and Gas Exchange Alterations during Intralipid Infusion in Patients with Adult Respiratory Distress Syndrome. Chest, 95(6), 1278-1281. https://doi.org/10.1378/chest.95.6.1278

Waitzberg, D. L., Torrinhas, R. S., \& Jacintho, T. M. (2006). New Parenteral Lipid Emulsions for Clinical Use. Journal of Parenteral and Enteral Nutrition, 30(4), 351-367. https://doi. org/10.1177/0148607106030004351

Weinberg, G. L., Di Gregorio, G., Ripper, R., Kelly, K., Massad, M., Edelman, L., Schwartz, D., Shah, N., Zheng, S., \& Feinstein, D. L. (2008). Resuscitation with Lipid versus Epinephrine in a Rat Model of Bupivacaine Overdose. Anesthesiology, 108(5), 907-913. https:// doi.org/10.1097/ALN.0b013e31816d91d2

Weinberg, G, Ripper, R., Murphy, P., Edelman, L., Hoffman, W., Strichartz, G., \& Feinstein, D. (2004). Lipid Infusion Accelerates Removal of Bupivacaine and Recovery From Bupivacaine Toxicity in the Isolated Rat Heart. Regional Anesthesia and Pain Medicine, 31(4), 296-303. https://doi.org/10.1016/j.rapm.2005.02.011

Weinberg, G. L., VadeBoncouer, T., Ramaraju, G. A., Garcia-Amaro, M. F., \& Cwik, M. J. (1995). Pretreatment or Resuscitation with a Lipid Infusion Shifts the Dose-Response to Bupivacaine-induced Asystole in Rats. Anesthesiology, 88(4), 1071-1075. https://doi. org/10.1097/00000542-199804000-00028

Weinberg, Guy. (2003). Lipid emulsion infusion rescues dogs from bupivacaine-induced cardiac toxicity. Regional Anesthesia and Pain Medicine, 28(3), 198-202. https://doi.org/10.1053/ rapm.2003.50041

Weinberg, Guy. (2006). Lipid Infusion Resuscitation for Local Anesthetic Toxicity: Proof of clinical efficacy. Anesthesiology, 105(1), 7-8. https://doi.org/10.1097/00000542-200607000-00005

West, N., \& Rusbridge, C. (2021). Ethanol toxicity in a dog due to ginsoaked sloe berry ( Prunus spinosa ) ingestion. Veterinary Record Case Reports, 9(1), e12. https://doi.org/10.1002/vrc2.12

Westropp, J. L., Buffington, C. A. T., Chew, D., Ettinger, S. J., \& Feldman, E. C. (2005). Textbook of Veterinary Internal Medicine. Elsevier Saunders Philadelphia.

Williams, K., Wells, R. J., \& McLean, M. K. (2015). Suspected synthetic cannabinoid toxicosis in a dog. Journal of Veterinary Emergency and Critical Care, 25(6), 739-744. https://doi.org/10.1111/vec.12378

Wright, H. M., Chen, A. V, Talcott, P. A., Poppenga, R. H., \& Mealey, K. L. (2011). Intravenous fat emulsion as treatment for ivermectin toxicosis in three dogs homozygous for the ABCB1-1 $\triangle$ gene mutation. Journal of Veterinary Emergency and Critical Care, 21(6), 666-672. https://doi.org/10.1111/j.1476-4431.2011.00687.x

Xenoulis, P. G., Suchodolski, J. S., Levinski, M. D., \& Steiner, J. M. (2008). Serum liver enzyme activities in healthy Miniature Schnauzers with and without hypertriglyceridemia. Journal of the American Veterinary Medical Association, 232(1), 63-67. https://doi. org/10.2460/javma.232.1.63 